\title{
OMNIVOROUS FICTION: BRAZILIAN NOVEL OF THE NOW
}

\author{
FICÇÃO ONÍVORA: O ROMANCE BRASILEIRO DO AGORA
}

Miguel Sanches Neto ${ }^{1}$

\begin{abstract}
Resumo: Em uma tradição periférica, marcada por atrasos estéticos, o a produção romanesca no Brasil usa o conceito de apropriação, não de códigos de grandes autores específicos. Ela utiliza elementos de vários gêneros narrativos, desfazendo os limites entre eles. Tal prática dá ao romance contemporâneo brasileiro um status de síntese da narrativa pós-moderna, em que outros modos de narrar são experimentados. Como tal, ela é marcada por uma vitalidade ficcional de nações abertas a empréstimos e saques. Este ensaio analisa as linhas de força principais da atual produção romanesca e propõe um autor como a fonte principal.
\end{abstract}

Palavras-chave: Romance brasileiro, entretenimento, experimentação, pós-modernidade

\begin{abstract}
In a peripheral tradition, marked by aesthetic delays, the novel production in Brazil uses the concept of appropriation, not of codes of great specific authors. It uses elements from several narrative genres, undoing the limits among them. Such practice gives the contemporary Brazilian novel a status of synthesis of the postmodern narrative, in which other ways of narrating are experimented. As such, it is marked by a fictional vitality typical of nations open to borrowings and lootings. This essay analyzes the main lines of force in Brazilian current novel production and proposes an author as the main source.
\end{abstract}

Keywords: Brazilian novel, entertainment, experimentation, postmodernity

\section{The Age of Novelists}

As a seismographic assessment of the contemporary publishing market is no longer possible and as, at the same time, there is an increasingly pressing need to know this production, it is up to researchers working with recent literary manifestations to attempt to place some significant books and authors within representative lines of force. This essay combines critical and historiographical perspectives while renouncing totalizing gazes by giving precedence to a metonymic vision.

There is a disturbing factor in this analysis generated by the identity of the self that produces it; an I that, in addition to the extensive practice of militant criticism, the one which evaluates books as soon as they are launched, still writes novels regularly, and thus, can have both an outside and an inside view of the novelistic process. The critical judgment about today's Brazilian novel, therefore, is indistinguishable from the options that this "I" has found available in the tradition it has helped to strengthen. The novelist's understanding of his subject cannot be taken as inferior to that of the critic or essayist, and perhaps could even be regarded as more vital, for his intervention in the narrative field depends upon it. This internal criticism, which is usually lodged in the pages of intimate diaries, dialogues here with the essay itself, in a

\footnotetext{
${ }^{1}$ Ponta Grossa State University - UEPG, Ponta Grossa, Paraná, Brasil; https://orcid.org/0000-0003-4778-2655; reitoria@uepg.br
} 
movement of overlapping purposes: writing criticism to understand the contemporary panorama and to understand oneself.

Then, the first question that arises in the beginning of a text of this nature is: why the novel? This question leads to another: what is its centrality in the set of literary and non-literary texts of the now? Production in a particular genre does not reflect a vocation of an individual or of groups - a strength of the mystique of the self - because they are primarily responses to needs of expression and market opportunities. The generic entity called "author" takes the shape of a novelist, a short story writer, a poet, a chronicler, etc. mostly in response to external stimuli which are historical in nature. Thus, it is necessary to verify how the contemporary Brazilian novelist is born and how the power of this genre is established in our country. It is his capacity for intervention that puts him at the center of the field of literary power.

During the military dictatorship (1964-1985), there was a hegemony of the short story due to the need for a rapid response to the moment of suppression of rights and the persecution and death of militants. The historical urgency leads to an urgency of production and consumption. The form of publication available to authors also increases the strength of this language. Printed on homemade mimeographs outside the publishing system, short stories could circulate through direct contact between author and reader, as an ideological password, circumventing censorship. Writing, publishing and reading short stories become tasks of resistance against the dictatorship and eventually create an underground network of literary circulation. With the successive relaxation of the repression, the short story finds shelter in publishing houses - not without the appearance of lawsuits against authors and publishers, nonetheless - and becomes the strongest medium of this period. Brazil then becomes a country of short story writers, and they are scattered throughout all its latitudes and not just concentrated in the cities that dominate the publishing market. The popularization of the short story contributes to the rediscovery of deep Brazil and fills the literary map of the country in an unprecedented way. Medium-sized inland cities gain unthinkable editorial density outside this context of resistance. Limiting ourselves to just one example, we may note that Londrina, in the northern part of the southern state of Paraná, is the home of the most important young short story writer of the moment. Domingos Pellegrini (1949-) began publishing short stories and poems in mimeographed notebooks of his own, in which he was also an illustrator and editor, as in the historical Vitamina de Pobre é Poeira (1969), and eventually released one of the most emblematic collections of the time by a major publishing house from Rio de Janeiro - O Homem Vermelho (Civilização Brasileira, 1977) - Jabuti Award winner that same year. The title itself, a semantic game valid both as a reference to the red earth, the region in which the narratives take place, and as a revelation of its political commitment, valuing a leftist ideology, displays the orientation of young authors of the period, who sought to oppose a right-wing government and the instruments of aesthetic production within the logic of the market.

With the end of the dictatorship and the exhaustion of a narrative model dominated by the short story, Brazilian production gives way to the novel, which occupies most of the editorial spaces, reaching great levels of professionalization, with the emergence of new publishers who want to update their offer of titles. This transition, therefore, occurs when Brazilian literature suffers a much greater impact from international production - the opening of the market to translations of novels from various languages into Portuguese - and when it seeks to interfere in the global scenario, producing a cosmopolitan perspective. Brazil is no longer a country in a state of exception, and it needs to participate in the concert of the democratic nations of the West.

And as the novel travels better to other languages, it was summoned as an artifact of international interface. It is notorious that, in recent decades, this genre has functioned as a point of dialogue between cultures, leading to a permanent update of peripheral references, while allowing the peripheral to exert a countercurrent force, asserting itself outside its place of origin. 
This benefited the Brazilian novel, which was reinventing itself after a long period of conditioning to a national political circumstance. Orhan Pamuk, in The Naive and Sentimental Novelist, highlights this updating role of the novel, which addresses different audiences in more remote societies, fulfilling a function we could define as civilizing. He concludes: "Communication through literature, in or outside the West, is predominantly carried out through the novel ${ }^{2} . "$

Brazil finds in this narrative format a possibility to cross the country's borders and participate in the universal now without renouncing national dilemmas. Thus, the contemporary Brazilian novel has to be thought of more as a contemporary novel than as strictly Brazilian, since it has integrated itself into a hegemonic current of world production.

Following the novelist Pamuk, it is argued here that studying the manifestations of the contemporary novel allows us to understand how this "communication" between nations and groups takes place, and what are its tensions, such as that established between the democratizing power of art and its connections to the market.

While the novel occupies a central place as a genre, this position generates a critical discourse of denial. After successive attempts to decree its death at other times in history, a new wave of rejection emerged. For some of the critics, the novel has become the reverse of art, as seen in the essay Do not Encourage the Novel ${ }^{3}$ by the Italian critic Alfonso Berardinelli. For him, who works mainly with poetry, what compromises the aesthetic element of the novel is its mass production. In this essay, he shows the transition from the self-denial of the art of the New Novel to the second youth of this genre which was undertaken by Latin American narrators, who make themselves known for the large number of narrable facts typical of rich and culturally unknown continents. This is the moment of enthusiasm for the novel created by the logic of bestsellers. The critic opposes to such consumerist perspective, seeing in the novel a danger to everyone: "This optimism is part of that widespread, fatally hypocritical cultural democracy that must offer everyone the possibility or illusion of being everything: even a novelist. That is, democracy kills the novel by encouraging it" ${ }^{\text {" }}$. His stance is, thus, contrary to that of Orhan Pamuk and other novelists and critics who find in the novel a way of speaking to more heterogeneous audiences.

\section{Novel as Transgression}

Identifying the main paths taken by contemporary Brazilian novelists, in this perspective that they are integrated into the world debate, may allow a more grounded evaluation of this hegemonic literary form, so that its behavior in relation to public expectations can be studied. The arrival of Brazil to contemporaneity always suffers delays and has to be permanently reaffirmed, as if we were condemned to a chronic lag. Is the market-novel practiced in recent decades a renunciation of the art-novel advocated by the most purist critics? Would postmodernity as an instrumental strategy disqualify recent production, leaving the worn-out radicalization of the avant-garde only to 'real writers'? These questions point to the need to better understand the dilemma of the Brazilian novel, stuck more than once in its peripheral position, which paradoxically creates complexes of extreme artistic superiority based on resentful reasoning: "We have no market for art, so let's look for an art against the market". In a preliminary analysis, it can be noticed that the values of the Brazilian novel undergo a sudden change from the 1980s onwards. In the previous two decades, there was a polarization between the experimental and the political novel. The experimental line of force was divided into two

\footnotetext{
${ }^{2}$ Translated by Nazim Dikbas. London: Faber \& Faber, 2011, p. 188.

${ }^{3}$ Non incoraggiate il romanzo. Padua: Marsilio, 2011.

${ }^{4}$ Lucia Wataghin (Editor). São Paulo: Nova Alexandria / Humanitas Editorial, 2007, p.179.
} 
nuclei, one, more rational in nature, of which Osman Lins's (1924-1978) Avalovara $(1973)^{5}$ is a great example, and the other, more Dionysian in nature, as can be seen in Galvez, Imperador do Acre (1976) ${ }^{6}$, by Márcio de Souza (1946-).

At the other pole, the novel could be political within a realist grammar, such as Quarup (1967) ${ }^{7}$ by Antonio Callado (1917-1997), or it could be allegorical-political, one could remember, among many other books, A Hora dos Ruminantes $(1966)^{8}$, by José J. Veiga (19151999). In these two modalities, experimentalism functions as a denial of novelistic language as a strategy of sabotaging society - the political novel as a direct or allegorical way of criticizing the system, but without breaking completely with the codes of linguistic and aesthetic recognition. The field of action of the literary novelist was extremely restricted, and was conditioned to an intervention against the social and political values that prevailed in the country. Negativity (of the social and / or language model) as the essence of novelistic making was the only critically validated literary strategy. In other words, Brazil has been for decades giving answers to an internal situation, moving away from the international artistic flow. It is during this period that the critics that would guide specialized artistic consumption are trained at universities, most of them are still active. With political openness, mass media, newspapers, magazines, cinema and television, at first, and later the internet and Netflix, will contaminate in the positive and negative sense of the verb - the Brazilian production, leading to a wave of both denial of the novel as entertainment, and naive adherence to this new possibility of the novel as a mere item in the market of disposables.

Evidently, this is not an isolated Brazilian phenomenon, although it has a greater impact on our production, creating radical debates between critics and producers, due to the lack of a wider public that could also consume great art. The limitation of audience in Brazil forces a disproportionate reaction to entertainment connections, which negates the communication task of our novel.

But the fact is that in the last three decades there has been an integration of the world through consumption. An internationalist energy is being more intensely felt and the Brazilian novel finds itself within a market (albeit a shy one), produced within a horizon of acting on large audiences. The rules of production dialogue more explicitly with the forms of reception, which would be responsible, according to the most apocalyptic arguments, not without some nostalgia for the previous stage, for the death of this genre as an art.

Against simplistic polarizations, which serve as comfortable discourse, suspending the need to think, since their advocates are moved by beliefs, it is necessary to see the Brazilian novel within a pluralist panorama, in which the genre feeds back into conflict with other languages. This permeability of the novel to other forms of expression is the guarantee of its permanence even in the most adverse contexts - when its death is said to be the inevitable result of the hegemony of new art forms - and should be valued as a survival strategy. Its production that reaches literary lay audiences is not a simple delivery to the market but a way of cultivating the founding principles of modern literature, with new guises, meeting a consumerist propensity of certain segments of the population. Even when fiercely fought, the novel has incorporated the negatives, the codes that competed with it, making everything that denied it become an extension of the very concept of novel. It, thus, reaches contemporary times with great conceptual elasticity. Everything can be included in the novel. From the most traditional story to the most radical experimentation. It is in this perspective that we could identify some lines

\footnotetext{
${ }^{5}$ Available in English as: Avalovara. Translated by Gregory Rabassa. Chicago, Ill: Dalkey Archive Press, 2002.

${ }^{6}$ Available in English as: The Emperor of the Amazon. London: Sphere Books, 1982.

${ }^{7}$ Available in English as: Quarup; A Novel. New York: Knopf, 1970.

${ }^{8}$ Available in English as: The Three Trials of Manirema. New York: Knopf, 1970.
} 
of force in contemporary production that communicate with each other, because many authors move through more than one of them, given the fluctuating format of the genre itself.

Still tied to a self-denying view of critical modernity, some novelists use the novel to question language. This transgression can be thematic when choosing a universe, a social group or a character type causes a shock to the inadvertent reader. But it can also be a transgression of language or structure, allowing one to question the ways of narrating, thus exercising a structural negativity that is critical to society. In some authors, these two forms of transgression overlap, in a double negativity.

This lineage is the most prestigious both in academia and in the media, as it ties today's novel to avant-garde values that have verticalized the arts. However, this transgressive function is no longer in the previous context, but within a highly industrial mechanism, that is, it responds to an art consumption desire proper to a literary literate public. It is more like a brand, more linked to an idea of prestige than to a critical rupture. It is a kind of programmatic nihilism, written to the taste of a certain academic public. Even when communicating with this narrative negativity, the novel remains a means of communication.

A contemporary classic of narrative transgression, Sérgio Sant'Anna (1941-2020) has always sought to bring the novel closer to other genres. In Um Crime Delicado (1997), this dialogue takes place with an artistic installation that sucks into its interior a rational critic who then becomes part of it. In love with a young model with a disability, he sexually takes advantage of being fragile and engages in what was meant to be contemplated only. The novel is a defense of this visceral relationship with the work of art, a space of very flexible boundaries, both materially and behaviorally.

In this group, among the well-made books, one must highlight Eles Eram Muitos Cavalos (2001) ${ }^{9}$, by Luiz Rufatto (1961-), in which the narrative is not in the plot, but in the structure. The meaning appears out of place, demanding a finer perception from the reader so that s/he can go further. Composed of small episodes, fragments of the most diverse texts, collected during an urban day, the book has as its protagonist the city of São Paulo, with its vast range of beings and dramas in a state of social atomization, where each cell lives independently and distant from the others, despite the spatial proximity.

The novel is a succession of reports, speeches and languages that are aggregated in an order that can be seen as ascending because the continuity of the texts, invariably short, creates the temporal rhythm that drives the reader from dawn to night. Refusing the traditional narrative time, which manifests itself in a chronological order linked to stable identities, the work introduces another temporality, in which there is a turmoil, a whirlwind, which leads us to perceive the city as a single temporal block, in which everything blends into a mind-blowing gift, as in a trance, a delirium. The city is this time exploding in a unique moment, amorphous, terrible. The technique used by the author is that of bricolage, the collection of texts, stories and language without a fixed narrative structure.

After this highly successful novel debut, Luiz Rufatto has been moving closer to more traditional formats, returning to a realism of structure and language, without ever distancing himself from the construction of novels that are juxtaposed stories. Younger authors keep this tradition of transgressive structures active, such as Joca Reiners Terron (1968-), with the recent Noite Dentro da Noite (2017), and the first-timer Aline Bei (1987) with O Peso do Pássaro Morto (2017).

\section{The Plurality of a Genre: Novel as an Essay, History or Entertainment}

\footnotetext{
${ }^{9}$ Available in English as: There Were Many Horses. Translated by Anthony Doyle. Seattle: Amazon Crossing, 2014.
}

Rev. Bras. Lit. Comp. Niterói, v. 22, n. 41, pp. 58-71, set. /dez. 2020 
With the closing of critical discourses, produced more for consumption within universities and for expert readers, and, in a more schooled society where the desire for knowledge grows reinforced by tumultuous online information, an environment of fruition arises for artistically dissertative novels, in which there is a theoretical reflection on the most varied subjects, from habits of other societies to literary culture.

According to what Isaac Bashevis Singer states in the preface to one of his short story anthologies ${ }^{10}$, literature has always had the function of entertaining and informing. This branch of the novel meets a desire for knowledge (that of "cultural democracy" of which Berardinelli speaks) without giving up entertainment. Structurally, this novel places in the plot a preoccupation with the discussion of ideas, functioning as an essay with narrative structure and literary language.

A paradigmatic case of this trend is Alberto Mussa's (1961-) O Movimento Pendular (2007). The author invests in the structure of the academic essay, with footnotes, abstracts, lines of research and index, all put at the service of the narrative. What determines the novelty of the book is the narrator created by Mussa - a man who wants not only to tell a story, or a set of stories, but to create a system.

There is a logical principle that governs the entire book, already announced at the opening, when the narrator declares the desire to write a theory of love triangles according to strictly mathematical criteria. And the reader will find formulas, geometric figures, and especially Cartesian deductions that produce reflective detachment in stories that are generally erotic.

The essayistic framework of the book also has a welding function. It is through such framework that the author can unite distant stories in time and space, which do not have apparent relations of continuity. Such relationships exist, but they have a deeper nature, no matter how different the reports are, they all confirm a rule. Thus, the book is organized rather by the structure of the entries - like a dictionary or encyclopedia - than by the internal connections of cause and effect. There is no narrative development, but overlapping and nonsuccessive case studies. What guarantees unity is precisely the theoretical apparatus, which gradually draws the typology of love triangles. Thus, the novelistic format is born from the systematizing interference proper to the essay. O Movimento Pendular is a novel because, first of all, it is an essay.

Even in the author's titles of crime novels that take place in past centuries, the tendency for the reflexive verb is still very strong. In other authors, we also find this essay flavor, in dissertative grammars, such as in Cristovão Tezza's (1952-) recent novel, A Tirania do Amor (2017), in which the narrator Otavio Espinhosa, a financial market animal, also with a mathematical head, makes a journey through Brazil's polarized politics and its economy, while remembering a book-length essay that would have saved him from mediocrity - Os Funcionários da Coroa - an explanation of the country by its statist logic, an abandoned academic work, which signals the interruption of his talent.

Essayism, therefore, penetrates the contemporary Brazilian novel.

Still within this binomial "information / enjoyment", a considerable part of the novelists began to produce narratives located in other temporalities, bringing to literary illiterate readers a modern view of historical facts, often transplanting current concepts into remote places and times.

With a wide range of historical episodes that are prone to be turned into novels, Brazil is an endless source of fiction material, which allows for a production that speaks of the past to refer directly to the present. Thus, the historical novel is historical only to some extent, meeting the urgency of understanding the now. It is almost always a historical metonymy. It speaks of

\footnotetext{
${ }^{10} 47$ contos. Tradução de José Rubens Siqueira. São Paulo: Companhia das Letras, p. 416.
} 
another time, with an extemporaneous view of those episodes, to interfere in the now. Here, the plot is the center of the narrative and the concept of truth is larger than the concept of fact with which historians work.

A symptom of this desire for knowledge of the past that serves the present is the amount of biographies and historical reports that has been produced in recent decades. In these other genres, facts, treated lightly, are worth more than the narrative structures that are the essence of the historical novel.

One of the biggest names in Brazilian literature of femine expression, Ana Miranda (1951-) made the historical novel her main form of expression. She practiced it in its postmodern version, which prescribes the creation of counter-narratives based on other works. Boca do Inferno (1989) ${ }^{11}$, for example, is a parallel song to the work of Gregório de Matos and other baroque authors. The historical concern of the writer manifests itself in parallel with a feminine outlook.

Desmundo (1996) is the story of Oribela, one of the orphans sent to Brazil in 1555 to set up families with Portuguese settlers. The novel is narrated in the first person. There is, say, no literary contract between the sender and the receiver. The narrator does not perceive herself as someone who is writing literature. The book is a collection of small soliloquies through which Oribela broods over her adventures and misadventures, her fears and the collective imagination of a country that is foreign to her. This causes the reader, one s/he accepts what the novel proposes, to be swallowed up by an extraneous time. We are not Oribela's interlocutors, but spies on his most intimate ideas and feelings.

Although focused on a love story as a way of overcoming orphanhood, Desmundo is really about the denegativization process of our country. The orphanhood of the colonizer is resolved in motherhood / fatherhood, the announcement of the transformation of the jungle into civilization.

In the book, from a structural point of view, fragmentation and narrative progression by accumulation, instead of by articulation, prevail in the narrative innovations that dialogue with the vanguards. Other writers, however, practice a more traditional historical novel with high literary quality, such as Luiz Antonio de Assis Brasil (1945-), a name that is practically indistinguishable from this strand, and which locates his texts in the far south of the country. It is worth highlighting some of his books, such as Videiras de Cristal (1990), Concerto Campestre (1997) and $O$ Pintor de Retratos (2001).

The connection with film and television, the major audience builders for the novel, led to a rapprochement between narrative and screenplay. The fact that in Brazil there has also been a growth in cinema, allowing a timid professionalization of writers outside of literature, intensified the impact of visual media on narrative material. Many writers assume this explicit connection with cinema, but without giving up the desire to make great literature, as we can see in the practice of a crime novels which do not completely surrender to the clichés of the genre, while still using them.

The writer appropriates some expedients of crime novels, in order to reach a larger audience, without giving up the task of literature, which is to give an unhappy conscience to the reader - according to Jean Paul Sartre's definition: "to make sure no one can ignore the world and feign innocence. " 12

In times of audience crisis, this approximation towards the criminal novel format brings readability to fiction, and leaves positive balances, such as $O$ Invasor (2002), by Marçal Aquino (1958-). Symptomatically born before as a screenplay of the same title, the novel is a good example of this more mediatic trend, in which the differences between literature and an

\footnotetext{
${ }^{11}$ Available in English as: Bay of All Saints and Every Conceivable Sin. New York, NY: Viking, 1992.

${ }^{12}$ Que é Literatura? Translated by Carlos Felipe Moisés. São Paulo: Atica, 1989, p. 21
} 
audiovisual production focused on violence in Brazil, a criminal theme par excellence, are blurred. In this novel, there is an interpenetration of the two social extremes of the city of São Paulo, that of the successful and privileged, represented by engineer Estevão, a majority partner in a construction company, who wants to get rid of other partners - who are friends from college and specimens of a middle class that seeks to ascend by choosing not very ethical alternatives - and Anísio, an ambitious and skilled killer. The construction company is the legal hub of the business investment, but there is a brothel, owned by one of the partners, Alaor, which is the rotten part of it. The distance between the two universes, that of the reputable firm, which does not accept, by decision of its main owner, a fraudulent scheme with politicians in Brasília triggering all the friction, and that of the house of prostitution, is only apparent. Estevão, for all his honesty, is a brothel-goer, and his daughter, the rebel Marina, has connections, due to her addiction, to the underworld of drug trafficking. This is São Paulo according to Marçal Aquino, a city that is the synthesis of contemporary Brazil, which has all its spaces invaded by banditry and the unethics of anything-goes, in a novel about Brazil caliber .38, with drugs, executions, blackmails and other crimes.

Among the young fictionists who follow this avowedly commercial avenue, one should mention Raphael Montes (1990-), who is also a screenwriter, writing in tune with Hollywood's crime and horror narratives, and who had his debut novel (Dias Perfeitos, 2014 ${ }^{13}$ ) a commercial success which was a strong candidate to become an international bestseller.

\section{Novels by the "Also" Writers and the Novel as Reinvented Experiences}

In a market oppressed by the lack of literary public, where national fiction occupies a smaller place on the shelves, a business was created with the adhesion, as authors, of great personalities from various areas. Once there is a popularization of novelistic structures, mainly through the enjoyment of TV series and films, this grammar at its most basic levels can be practiced by people who are not exactly writers. Actors, musicians, journalists and television presenters, with a large audience, diversify their products by offering novels, which miraculously make overnight hits, because what sells these works is not the that there is literature in them, but the power of the name that signs them. There are many cases of these professionals from other fields who also offer competently sketched novels that arrive at bookstores with a fuss. One example. Comedian and television host Jô Soares (1938-) brings Sherlock Holmes to Brazil to unravel the identity of a serial killer in a narrative focused entirely on entertainment, a mix of worlds, people and cultures - O Xangô de Baker Street $(1995)^{14}$.

Recently, the actress Fernanda Torres (1965-) has also ventured into the novel beginning her career as a novelist with Fim $(2013)^{15}$, a Rio de Janeiro story with the lightness of films and series starring the actress herself. The circulation of the book was intense, given the quality of the author's work as an actress. In a sterner field, economic journalist Miriam Leitão (1953-) became a novelist with Tempos Extremos (2014), an analysis of the military dictatorship era, anticipating current fears of a return to dictatorial rule by the recent rise of the right among us. With her attentive journalist's eye on the political scene, she used the novel as an extension of her social interventions.

If, for these personalities, the novel is an occasional event, two great names of Brazilian culture have systematically published titles in the area. The first of these is the singer and songwriter Chico Buarque (1944-), who debuted in literature with one of his parodies - Fazenda Modelo (1974) - a re-reading of George Orwell's Animal Farm, published in at a time of

\footnotetext{
${ }^{13}$ Available in English as: Perfect Days: A novel. Translated by Alison Entrekin. New York: Penguin Press, 2016.

${ }^{14}$ Available in English as: A Samba for Sherlock. New York: Pantheon Books, 1997.

${ }^{15}$ Available in English as: The End. Translated by Alison Entrekin. New York: Simon \& Schuster, 2017.
} 
censorship in Brazil. It is, however, from Estorvo (1991) onwards that he sought to build a career as a novelist in parallel to his multiple other activities, culminating in the 2019 Camões Prize, the most important literary prize in the Portuguese language. Addressing this debut novel, Wilson Martins defines Chico Buarque's writing practice as secondary: "Returning in Estorvo to the theme of urban violence coupled with the devastating alienation of the common man in the big city, Chico Buarque once again indulged in paraphrasing a much more vigorous and original literary work: Zero $(1975)^{16}$, by Ignacio de Loyola Brandão” (p.83).

Also leaving the world of music, in which he was a composer and Raul Seixas' partner, Paulo Coelho (1947-) became the most recognized Brazilian novelist in the world, explicitly within the logic of the bestseller. With mystical narratives and ready-made answers, repeated in his various novels, he confirms the reader's certainties and functions as a kind of spiritual advisor. Without Chico Buarque's varnish of erudition, he assembles his novels as rosaries of small parables, easy to read and full of encouragement.

In all these market level cases we fall short of the literary.

One of the dominant lines in national production is the autobiographical novel, autofiction or bionovel, which is favored by a local writing tradition. The connections between fiction and autobiography, common at other times in our history - such as in Raul Pompeia's O Ateneu (1888) ${ }^{17}$, Recordações do Escrivão Isaías Caminha (1909) by Lima Barreto, and Menino de Engenho $(1932)^{18}$ by José Lins do Rego - have undergone a radicalization in recent decades. The book that makes this transition from the disguised (often poorly disguised) autobiographical to the gaping autobiographical is Carlos Heitor Cony's (1926-2018) Quasememória, quase-romance (1995), in which the idea of frontier is explicit in the title, followed by Chove sobre minha infância (2000) of my own, a fictional study of the writer's birth in a family of illiterate workers.

There is, however, an earlier landmark, the life story of the poor boy who comes from a dissolute family and who carries a horrific crime as his childhood trauma, in José Carlos Oliveira's (1934-1986) O Pavão Desiludido (1972), a book assembled from his contributions to newspapers. In the last two decades, a large number of works has expanded this aspect, making it one of the most representative of contemporary production.

This great offer is explained by our tradition, dominated by the genre of the literary chronicle, which is prone to confessions of a self that wants to show itself. Brazilians, especially in the chronicle space, intensely and uninhibitedly use the first person singular, thus being predisposed to autofiction. What was a local historical trend, is intensified by internet writing, which encourages the use of the first-person, through which narrative theories of the self are developed.

The confluence of these two factors has produced a boom in autofiction in the country, didactically represented in a didactic manner in two recent titles: Cristovão Tezza's $O$ Filho Eterno (2007) ${ }^{19}$ and Marcelo Mirisola's (1966-) Como Se Eu Me Fumasse (2018). Tezza is an Apollonian author who focuses on literary language as a way of reflection, and who uses the resource of telling his own biography in a novel format only in this book. The traumatic point that triggers such narratives is, in this author's case, the birth of a child with Down's syndrome and the refusal he suffers on the part of his father, who secretly wishes for his death. A highly cathartic novel, it helped to make the author accept his son and establish an intense form of love. A recent great success of Brazilian fiction, O Filho Eterno is all written in the third person,

\footnotetext{
${ }^{16}$ Available in English as: Zero. New York, N.Y.: Avon Books, 1983.

${ }^{17}$ Available in English as: The athenaeum: a novel. Translated by Renata R. Mautner Wasserman. Evanston, Illinois: Northwestern University Press, 2015.

${ }^{18}$ Available in English as: Plantation Boy. New York: Knopf, 1966.

${ }^{19}$ Available in English as: The Eternal Son. Translated by Alison Entrekin. Dartmouth, Massachusetts: Tagus Press at UMass Dartmouth, 2013.
} 
in an attempt to control emotional language. Cristovão Tezza is a he revealed by Cristovão Tezza.

In the opposite field, Marcelo Mirisola assumes himself as Dionysian, indulging himself so unarmedly in all his personal experiences, in a perverse novel against the idea of family and love. Como Se Eu Me Fumasse continues an entire work written with lived material, without filters, in the real time of experience itself. If $O$ Filho Eterno is about redemption, this other novel reveals the dissolution of a self that does not forgive anyone, family, friends, or girlfriends, but mostly does not forgive itself. Strong and bitter, it is a narrative of violence against self.

In this same field of suspension of the barriers that can be narrated about life itself is Pai, pai (2017), by the writer and LGBT activist João Silvério Trevisan (1944-), a scrutiny of his own sex life, which begins with his desire still in childhood for brute men and ends in the author's old age, with a relationship with a young man. As every great book of autofiction has a scandal, the narrator here confesses that, as a child, he desired his own father. In adulthood he becomes himself the symbolic father of his much younger companions.

\section{Novel of the Identity Discourse and Immigration Novels}

In addition to this mode of heroicization of the narrator that refers to the author's name, there is another modality of the autobiographical, collectivist novel, which is the narrative focused on places and social languages from which the author comes from. The autobiographical here is not so much in the fictionalization of the experiences of a self but in the valorization of an identity discourse. They are narratives of the periphery, of marginalized social groups, whose great examples are Cidade de Deus $(1997)^{20}$, by Paulo Lins (1958-) and Capão Pecado (2000) by Ferréz (1975-). The classic of this lineage is Carolina Maria de Jesus' (1914-1977) journal-style novel Quarto de Despejo $(1960)^{21}$, in which a black single mother who lives in a slum builds her daily writing career while raising her children in inhumane conditions. Quarto de Despejo is a masterpiece produced by a woman with a low education, and yet has a raw mastery of literary language. In this field, the self-mimetism of languages and trajectories are of a collective nature.

More recently, the main black female voice of our time has taken central stage, after being left out for years, given the difficulty of these authors to reach the spaces of literary repercussion. We are referring to Conceição Evaristo (1946-), with her Ponciá Vicêncio $(2003)^{22}$, a narrative in which the humble origins of this black woman are the subject of the novel. While black authors have been obtaining demographic density in this area, few novelists among the indigenous people are. In this group, the production of children's literature prevails, given the structural similarity between legends and magical narratives for children. The most prominent name is Daniel Munduruku (1964-), who wrote O Karaíba: Uma História do préBrasil (2010), to give voice, in poetic (mythic) language, to the peoples who inhabited Brazil before the Portuguese arrived.

Within this same field of fictional restoration of origins, but more detached from a certain naturalism of language and plot, there is a proliferation of novels that study the arrival of immigrants, with the inevitable clash with local reality. Destination of various ethnic groups, which continue to operate within the national identity, Brazil acts as a sampling of the most diverse cultures, allowing novelists to fictionally study the implantation of another sociocultural

\footnotetext{
${ }^{20}$ Available in English as: City of God. Translated by Alison Entrekin. New York: Black Cat, 2006.

${ }^{21}$ Available in English as: Child of the Dark: The Diary of Carolina Maria De Jesus. Translated by David St Clair. New York: New American Library, 2003.

${ }^{22}$ Available in English as: Ponciá Vicencio. Translated by Paloma Martinez-Cruz. Austin, TX : Host Publications, 2007.
}

Rev. Bras. Lit. Comp. Niterói, v. 22, n. 41, pp. 58-71, set. /dez. 2020 
experience in the Brazilian matrix. Since Graça Aranha's (1868-1931) classic Canaã (1902)23, immigration (in that case, German) stands out as a Brazilian theme.

More recently, the great work is Raduan Nassar's (1935-) Lavoura Arcaica (1975) ${ }^{24}$, a story in poetic language, of a Lebanese family from the interior of the state of São Paulo, in which the hierarchical order is broken by the incestuous passion between siblings. A dissolution is born out of the descendant's contact with the tropical world in which he lives, a recurring record that comes from late nineteenth century naturalism, when Europeans departed from their traditions by adhering to local habits. In this same logic, but set in the Amazon, an ecological area of global interest, are the main novels by Milton Hatoum (1952-), such as Relato de Um Certo Oriente (1989) ${ }^{25}$ and Dois Irmãos $(2000)^{26}$. The latter, explores the tensions of a Lebanese family that begins in Manaus in the 1920s and extends to the years of the military dictatorship. It is a mixed family. Domingas, an Indian purchased from the nuns, seduces one of the twins, producing a bastard son, Nael, narrator of the story. It is this gaze, at once foreign and domestic, that reconstructs all the stations of the existential Via Crucis of a lineage split between two men, one an inconsequential bohemian, spoiled by a mother, who saw him as the most fragile, and the other, a man destined to work and achieve professional success. Generated at the same time, Yaqub was born minutes before Omar, and for that, he receives the nickname of Caçula, which means the youngest. The dispute for primogeniture occurs still in the womb, persisting throughout their lives, and causing suffering to those around them.

Competing all the time, the twins embody conflicting values. Omar's free and unruly life, which finds a place alongside the politically persecuted, is inversely proportional to his brother's opportunism, which works for the military. While one turns to poetry lived in the flesh, the other is devoted to mathematics and calculations. Caçula lives closer to the Manaus of the poor, of humble bars and fishermen, moving away from his brother who finds in São Paulo and in the cosmopolitan standard an antidote to his riverside childhood.

But if they represent the division of two worlds, Nael is the affirmation of mestizaje, the confluence point of East and West, interpreter of the meeting of two waters that form one of the images of our identity. The narrative is thus enhanced by this meaning that indirectly resolves the biblical conflict of the rebellious brothers.

A classic of the saga of Italian immigrants in Brazil, though not only about them, is Domingos Pellegrini's Terra Vermelha (1999). Starting from the decline, generated by a disorderly urbanization, and moving towards regaining, through remembrance, the values in crisis, the narrative is born out of the imbrication of two times, the heroic past and the petty and forgetful present. The history of a region which was a jungle until very recently, is seen from the trajectory of a common man, an anonymous hero of a universe that worshiped simplicity, to which the macrostructural events converge.

The novel reveals that it is in living with a dreamy and friendly people that joy lies. In several books by Domingos Pellegrini, the meaning of things arises from an identification with the earth, with the beings that live close to it, in intimate contact with the pre-urban, pre-asphalt world. The ancestral intimacy with the land makes his characters reenact the creation of the world in a region that was being pioneered and that would soon become another peripheral city of capitalism. The novel tells in anthological pages the creation and death of a world, but it also gives us the key to understanding the positive values of a colonization open to all mixtures.

\footnotetext{
${ }^{23}$ Available in English as: Canaan. Whitefish, MT: Kessinger, 2000.

${ }^{24}$ Available in English as: Ancient tillage. Translated by Karen Sherwood Sotelino. London: Penguin Books, 2015.

${ }^{25}$ Available in English as: Tale of a certain orient. London: Bloomsbury, 2004.

${ }^{26}$ Available in English as: The Brothers. London: Bloomsbury, 2003.
} 
It is a universe adjacent to another created by Oscar Nakasato (1963-), in Nihonjin (2011), which treats in a fragmented way the trajectory of the Japanese arriving in midtwentieth century Brazil.

In a more cosmopolitan field, the hallmark of young writers, we have Michel Laub (1973-), an author of Jewish origin, who develops in Diário da Queda (2011) ${ }^{27}$ the issue of the traumatic past, the memory of the holocaust and the oblivion from the family history of a writer from Porto Alegre, placed among the great ancestral dramas and an existence that seeks its place. The novel is a defense of remembering, a task that belongs to literature. In the same Jewish group is Tatiana Salem Levy's (1979-) novel A Chave da Casa $^{28}$, a reunion with the space of Turkish Jewish grandparents and with the political struggle of parents persecuted by the military dictatorship. What unites the two groups is the endangered minority condition, next to which the narrator stands.

The romance of immigration is always one of ethnic sums, fusion, one-sided acceptance conflicts, and identity recovery, fulfilling an important task in repositioning such a composite national identity.

\section{Contemporary contaminations and the Key-Novelist}

These are the main lineages of the contemporary novel. Their manifestations are not pure, they intersect, overlapping in different ways, but it is always possible to identify preponderances. In all of them, more or less intensely, there is an occupation of the narrative spaces of entertainment, meeting a market expectation. In good authors, however, this never leads to a dampening of tensions of language and society. These writers, even though writing in dialogue with the general public, rather than breaking away from it, they seek a broader reflection on the human condition, providing the audience with a little of what they expect as art and as a universe of reference.

If it is in its code not to give up this breadth of reception, the novel must prevent market logic from overriding literary logic. According to Berardinelli, in "The Postmodern Bestseller", this logic is characterized by producing: a relaxing and lightly therapeutic reading; hygienic or mental gymnastics reading - as the exercise of uncovering the riddle of the detective novel; a reading that acts like a drug, mesmerizing the reader with adventure, terror, comicality, sentimentality ...; and a culturally committed reading - for readers to acquire salon culture. Against these passive forms of enjoyment, the contemporary novel, in its greatest achievements, remains fully critical.

The hallmark of the novel has always been to appropriate everything that denied it, which wanted its end, and to make this denial a constituent part of its critical equipment. A very negative assessment of the contemporary novel - which deems it totally devoted to the logic of the market - ignores that, belonging to the now and addressing today's readers first, it cannot be refractory to the tensions of the present without falling into an artistic utopia.

The boundaries between high literature and mass literature are very unstable and there is a permanent reciprocal contamination. Even flirting with entertainment, literature will be creating dislocations, producing turmoil.

And then we reach the Brazilian writer who works as a catalyst for all these strands of the contemporary Brazilian novel. Going from crime stories (A grande arte, 1983) ${ }^{29}$, to the

\footnotetext{
${ }^{27}$ Available in English as: Diary of the fall. London: Vintage, 2015.

${ }^{28}$ Available in English as: The house in Smyrna. Translated by Alison Entrekin. Melbourne; London: Scribe, 2015.

${ }^{29}$ Available in English as: High Art. New York: Carroll \& Graf, 1987.
} 
historical novel (Agosto, 1990) ${ }^{30}$, to autofiction (José, 2011), to structural experimentation $(O$ Selvagem da Ópera, 1994), Rubem Fonseca (1925-) reaches the extreme of appropriation of the bestselling structure in his latest novels, something that has always been present.

The great merit of his novels lies in their ability to subvert mass reading codes. At the same time, Rubem Fonseca questions, by adhering to certain resources, the possibility of making a dense literature that haunts the reader in an age of superficial emotions and plots. And it does so using the codes of this moment, not wanting to affirm a leaflet aesthetic, but using it as a medium. The commercial format of his novels leads us to a degree zero of literature. From there below there is the non-literary, lawless land of text written to the reader's taste. But on the other hand, it enables entertainment consumers to get closer to the great literature. Novelist on this frontier, the epitome of an era, he is today what Machado de Assis was to Brazil in the late nineteenth century.

Translated by Alexander R. Luz.

\section{WORKS CITED:}

ARANHA, Graça. Canaan. Whitefish, MT: Kessinger, 2000.

BERARDINELLI, Alfonso. Non incoraggiate il romanzo. Padua: Marsilio, 2011.

BRANDÃO, Ignacio Loyola. Zero. New York, N.Y.: Avon Books, 1983.

CALLADO, Antonio. Quarup; A Novel. New York: Knopf, 1970.

EVARISTO, Conceição. Ponciá Vicencio. Translated by Paloma Martinez-Cruz. Austin, TX :

Host Publications, 2007

FONSECA, Rubem. High Art. New York: Carroll \& Graf, 1987.

Crimes of August: A Novel. Translated by Clifford E. Landers. Dartmouth,

Massachusetts: Tagus Press at UMass Dartmouth, 2014.

HATOUM, Milton. The Brothers. London: Bloomsbury, 2003.

Tale of a certain orient. London: Bloomsbury, 2004.

JESUS, Carolina de. Child of the Dark: The Diary of Carolina Maria De Jesus. Translated by David St Clair. New York: New American Library, 2003.

LAUB, Michel. Diary of the fall. London: Vintage, 2015.

LINS, Osman. Avalovara. Translated by Gregory Rabassa. Chicago, Ill: Dalkey Archive

Press, 2002.

LINS, Paulo. City of God. Translated by Alison Entrekin. New York: Black Cat, 2006.

MIRANDA, Ana. Bay of All Saints and Every Conceivable Sin. New York, NY: Viking, 1992.

MONTES, Raphael. Perfect Days: A novel. Translated by Alison Entrekin. New York:

Penguin Press, 2016.

NASSAR, Raduan. Ancient tillage. Translated by Karen Sherwood Sotelino. London:

Penguin Books, 2015.

PAMUK, Orhan. The Naive and Sentimental Novelist. London: Faber \& Faber, 2011.

POMPEIA, Raul. The athenaeum: a novel. Translated by Renata R. Mautner Wasserman.

Evanston, Illinois: Northwestern University Press, 2015.

REGO, José Lins do. Plantation Boy. New York: Knopf, 1966.

RUFATTO, Luiz. There Were Many Horses. Translated by Anthony Doyle. Seattle: Amazon

Crossing, 2014.

\footnotetext{
${ }^{30}$ Available in English as: Crimes of August: A Novel. Translated by Clifford E. Landers. Dartmouth, Massachusetts: Tagus Press at UMass Dartmouth, 2014.
} 
SARTRE, Jean Paul. Que é Literatura? Translated by Carlos Felipe Moisés. São Paulo: Atica, 1989.

SOARES, Jô. A Samba for Sherlock. New York: Pantheon Books, 1997.

SOUZA, Márcio de. The Emperor of the Amazon. London: Sphere Books, 1982.

TEZZA, Cristovão. The Eternal Son. Translated by Alison Entrekin. Dartmouth, Massachusetts: Tagus Press at UMass Dartmouth, 2013.

TORRES, Fernanda. The End. Translated by Alison Entrekin. New York: Simon \& Schuster, 2017.

VEIGA, José J. The Three Trials of Manirema. New York: Knopf, 1970.

Miguel Sanches Neto has a doctorate from Unicamp (Brazil) and a post-doctorate from the University of Minho (Portugal). Associate Professor at Ponta Grossa State University, he is also a novelist with several published titles, among them Chove Sobre Minha Infância (2000), Um Amor Anarquista (2005), A Máquina de Madeira (2012), A Segunda Pátria (2015), about Nazis in Southern Brazil, and A Bíblia de Che (2016). He received, among others, the Cruz e Sousa Award (2002) and the Binational Award for Arts and Culture Brazil-Argentina (2005). http://lattes.cnpq.br/0212593991244575

Submetido em 03/04/2020

Aprovado em 13/06/2020 